\title{
The exploitation of micromorphological parameters for identification in the section Mentha Využitie mikromorfologických parametrov pri identifikácii v sekcii Mentha
}

Abstract The identification of species in the genus Mentha is especially difficult because of the ease of hybridization, favoured by gynodioecy, which is further complicated by polymorphism, cultivation, polyploidy and vegetative propagation. This all explains the genicpopulation and microevolutionary background for variability of mints. In this work we studied the usage of micromorphological and phytochemical parameters in identification and characterization of selected Mentha species. On abaxial surface of leaves of 20 Mentha populations we determined the size and the number of peltate glandular trichomes. The essential oil was analysed by GC MS. We identified and characterized populations of $M . \times$ piperita, M. spicata, M. spicata subsp. condensata, M. spicata var. crispa, M. spicata var. citrata, $M$. $\times$ gentilis, M. aquatic, M. arvensis amd M. longifolia. The size and the number of peltate glandular trichomes contribute to characterisation of some Mentha species (especially in $M$. longifolia and M. $\times$ piperita).

Slovak Identifikácia druhov v rode Mentha L. je obzvlášt náročná. Je to spôsobené lahkým križením podporeným gynodioéciou, ktorá abstract je d’alej skomplikovaná polymorfizmom, pestovaním, polyploiditou a vegetatívnym rozmnožovaním, čo vysvetluje genetickopopulačné a mikroevolučné pozadie premenlivosti v rode Mentha. V tejto práci sme študovali využitie mikromorfologických a fytochemických parametrov pri identifikácii a charakterizácii vybraných druhov rodu Mentha. Na spodnej pokožke listov 20 populácii Mentha sme stanovili vel'kost’ a počet „žliazok typu Lamiaceae“. Silicu sme analyzovali pomocou GC MS. Identifikovali a charakterizovali sme populácie druhov $M$. × piperita, M. spicata, $M$. spicata subsp. condensata, $M$. spicata var. crispa, M. spicata var. citrata, $M$. $\times$ gentilis, M. aquatic, $M$. arvensis a M. Iongifolia. Sledovanie vel'kosti a počtu „žliazok typu Lamiaceae prispievajú k charakterizácii niektorých druhov Mentha (najmä M. longifolia a M. × piperita).

Keywords Mentha-peltate glandular trichomes-quantitative microscopy-essential oil-GCMS

Klúčové Mentha-žliazky typu Lamiaceae - kvantitatívna mikroskopia - silica-GCMS slová:

\section{INTRODUCTION}

The genus Mentha L. belongs to the family Lamiaceae, subfamily Nepetoidae. The taxonomy of the genus Mentha is still not definite but on the basis of a phylogenetic analysis of morphology, chromosome numbers, and major constituents of essential oil, the genus Mentha is now redefined to include 18 species and 11 hybrids placed in four sections: Pulegium, Tubulosae, Eriodentes and Mentha (Tucker \& Naczi, 2007). The pharmacological activities of mints are chiefly bound to the presence of two main groups of secondary metabolites: essential oil and phenolic compounds. Essential oil of mints is composed of monoterpenes and sesquiterpenes, which content vary from species to species (Lawrence, 2007). Essential oil is produced by specialized secreting tissues glandular trichomes (Gershenzon et al., 1989; McCaskill et al., 1992). Two types of glandular trichomes occur on mint's leaf surface: small, capitate trichomes, with a single secretory head cell (Figure 1) and peltate glandular trichomes (PGT), with an eight-celled head and huge subcuticular oil storage cavity (Figure 2). Recently, we published works aimed in identification by usage of different parameters: anatomical, morphological, phytochemical (Fialová et al., 2011; ŠarićKundalić et al., 2009). The aim of this study was further 


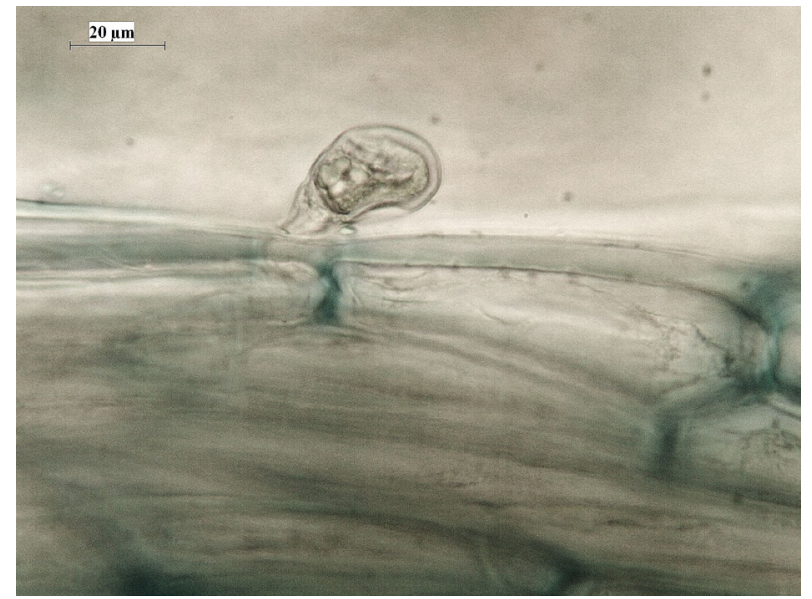

Figure 1. Capitate trichome, with a single secretory head cell

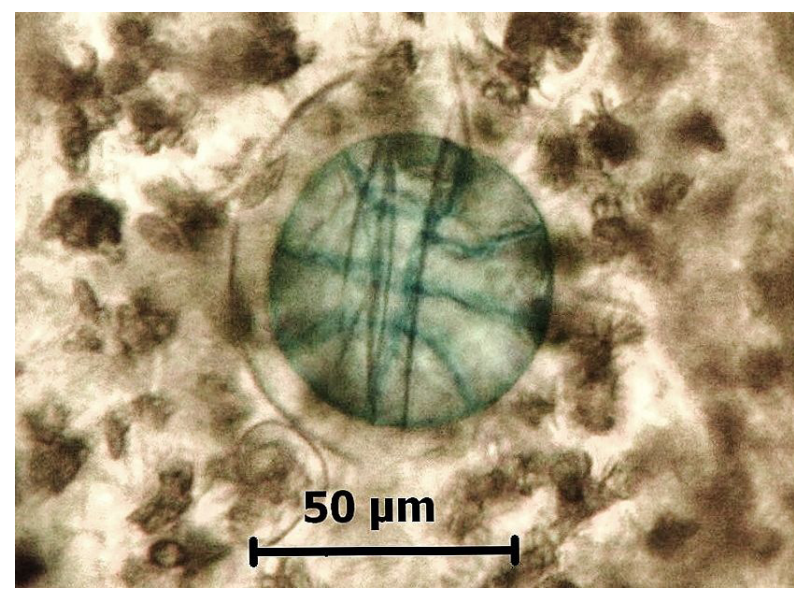

Figure 2. Peltate glandular trichome, with an eight-celled head

examination of usage of micromorphological parameters, specifically the size and number of peltate glandular trichoms, for the identification and characterization of different mints. We investigated the frequency and size of peltate glandular trichomes and validated this method as useful for the differentiation of Mentha species. For disquisitional identification it was necessary to determine the main components of essential oils.

\section{MATERIAL AND METHODS}

\subsection{Plant material}

The plants have been collected in different areas of south, south-west and middle Slovakia (Table 1). All plants were harvested in the stage of flowering, in sunny days. Plants was dried in an oven at $30-35{ }^{\circ} \mathrm{C}$, afterwards were kept in paper bags at room temperature. The voucher specimens are deposited at the Department of Pharmacognosy and Botany, Faculty of Pharmacy, Comenius University in Bratislava, Slovakia.
Table 1. Investigated mints and their origin

\begin{tabular}{|c|c|}
\hline Sample & Collection area \\
\hline Mentha spicata (V10) & $\begin{array}{c}\text { old genetic resources SUA } \\
\text { Nitra }\end{array}$ \\
\hline Mentha $\times$ piperita (V11) & $\begin{array}{c}\text { old genetic resources SUA } \\
\text { Nitra }\end{array}$ \\
\hline Mentha longifolia (V12) & $\begin{array}{c}\text { old genetic resources SUA } \\
\text { Nitra }\end{array}$ \\
\hline Mentha $\times$ gentilis (V13) & Komárno \\
\hline Mentha longifolia (V14) & $\begin{array}{c}\text { Garden of Medicinal Plants, } \\
\text { Bratislava }\end{array}$ \\
\hline Mentha $\times$ piperita (V15) & $\begin{array}{l}\text { old genetic resources SUA } \\
\text { Nitra }\end{array}$ \\
\hline Mentha $\times$ piperita (V16) & $\begin{array}{c}\text { old genetic resources SUA } \\
\text { Nitra }\end{array}$ \\
\hline Mentha spicata (V17) & $\begin{array}{c}\text { Garden of Medicinal Plants, } \\
\text { Bratislava }\end{array}$ \\
\hline Mentha $\times$ gentilis (V18) & Komárno \\
\hline Mentha spicata (V19) & Podkylava (Myjava*) \\
\hline $\begin{array}{l}\text { Mentha spicata var. } \\
\text { crispa (V22) }\end{array}$ & $\begin{array}{c}\text { old genetic resources SUA } \\
\text { Nitra }\end{array}$ \\
\hline Mentha × gentilis (V24) & $\begin{array}{c}\text { Garden of Medicinal Plants, } \\
\text { Bratislava }\end{array}$ \\
\hline Mentha longifolia (V43) & Zochova chata (Pezinok*) \\
\hline $\begin{array}{l}\text { Mentha spicata subsp. } \\
\text { condensata (V44) }\end{array}$ & Modra (Pezinok*) \\
\hline Mentha spicata (V46) & Modra (Pezinok*) \\
\hline Mentha arvensis (V50) & Revište (Žarnovica*) \\
\hline Mentha aquatica (V55) & Pezinok \\
\hline Mentha spicata (V57) & Modra (Pezinok*) \\
\hline $\begin{array}{l}\text { Mentha spicata var. } \\
\text { crispa (V59) }\end{array}$ & Komárno \\
\hline $\begin{array}{l}\text { Mentha spicata var. } \\
\text { citrata (V60) }\end{array}$ & $\begin{array}{l}\text { old genetic resources SUA } \\
\text { Nitra }\end{array}$ \\
\hline
\end{tabular}

SUA - Slovak University of Agriculture, ${ }^{*}$ region

\subsection{The quantitative microscopic analysis}

Anatomical analyses were carried out using Leica DME microscope (Leica, Germany) equipped with a Leica EC3 Digital Camera (Leica, Germany) and its equipment of software (Leica Application Suite 2.4.0 R1 LAS EZ ver. 1.3.0, Germany). Leaves were placed on a glass slide, embedded in few drops of $60 \%$ chloralhydrate and shortly gently boiled in order to clear the samples. For the observation we have selected only the leaf on stem placed as the fourth from the end of inflorescence (from the top). 


\subsection{The analysis of essential oil by GC-MS}

For GC MS (Shimadzu GCMS-QP2010) a Column Zebron capillary ZB-WAX $(0.25 \mu \mathrm{m}$ film thickness, $60 \mathrm{~m}$ length $\times 0.25$ $\mathrm{mm}$ ) was used, $50 \mathrm{mg}$ dry leaf sample were extracted in 500 $\mu \mathrm{L}$ dichloromethane and treated by ultrasonication for 10 minutes at room temperature. $1 \mu \mathrm{L}$ aliquots were analysed. The composition was reported as a relative percentage of the total peak area.

\section{RESULTS AND DISCUSSION}

We observed the abaxial surface of leaf due to the higher density of PGT in comparison to adaxial surface (Maffei et al., 1989; Turner et al., 2000). We measured the size of PGT and their number per $1 \mathrm{~mm}^{2}$. PGT appear from the top as formations of rounded shape; their size was expressed as the diameter of the circle in microns $(\mu \mathrm{m})$. For this analysis we used an optical microscope. The measurements were performed by the digital camera with measuring software. The camera was calibrated manually using a lens micrometre ( $1 \mathrm{~mm} / 0.01)$. For the analysis of each population we used at least 10 samples (10 leaves). The formation of peltate glandular trichomes is not synchronized; different developmental stage of PGT could be found on the same leaf. The PGT are developing while the meristematic activity of protoderm lasts. The size of PGT is therefore dependent on the leaf ripening. In our work, the size of PGT was measured on the fourth leaf from the end of inflorescences, which is considered to be sufficiently developed, meristematic activity is stopped and the constant size of the PGT is supposed.
Nevertheless, some minor changes in the size of PGT are generally connected with the aging of leaves. The size of PGT is an endogenously controlled sign (Felklová et al., 1986). The differences in number and size of PGT in mints were recorded in the past. Anyway, the majority of published works advert to peppermint and menthol type of mints (Maffei et al., 1989; Nátherová \& Lindauerová, 1986; Felklová et al., 1986).

\section{Number of PGT on leaves}

Maffei et al. (1989) investigated the correlation between PGT number and leaf length in peppermint. They found out a positive correlation between trichome number and leaf length, whereas the trichome density decreased with increasing leaf length. Our investigations comprised different mint species, where we observed the correlation between average leaf length and average density of PGT on surface area $1 \mathrm{~mm}^{2}$. Our results confirm the previous investigation. Anyway there are also some exceptions (Table 2). The largest PGT number on area $1 \mathrm{~mm}^{2}$ we found on $M$. spicata var. citrata (14.7 PGT/mm ${ }^{2}$ ). Similarly, large amount of PGT was found in all populations of $M . \times$ piperita (8-14 PGT/ $\mathrm{mm}^{2}$ ) and $M$. longifolia $\left(9-14.7 \mathrm{PGT} / \mathrm{mm}^{2}\right)$. The less number of PGT occurred in $M$. arvensis (3.6 PGT/ $/ \mathrm{mm}^{2}$ ) and $M$. $\times$ gentilis (3.6 5.6 PGT/ $\mathrm{mm}^{2}$ ).

\section{The size of PGT}

As we already published; the size of PGT could be helpful in mints identification (Fialová et al., 2011; Šarić-Kundalić et al., 2009). If the size of PGT on developed leaves is constant; our results showed that the largest PGT are presented in peppermint and spearmint (Figure $\mathbf{3}$ ).

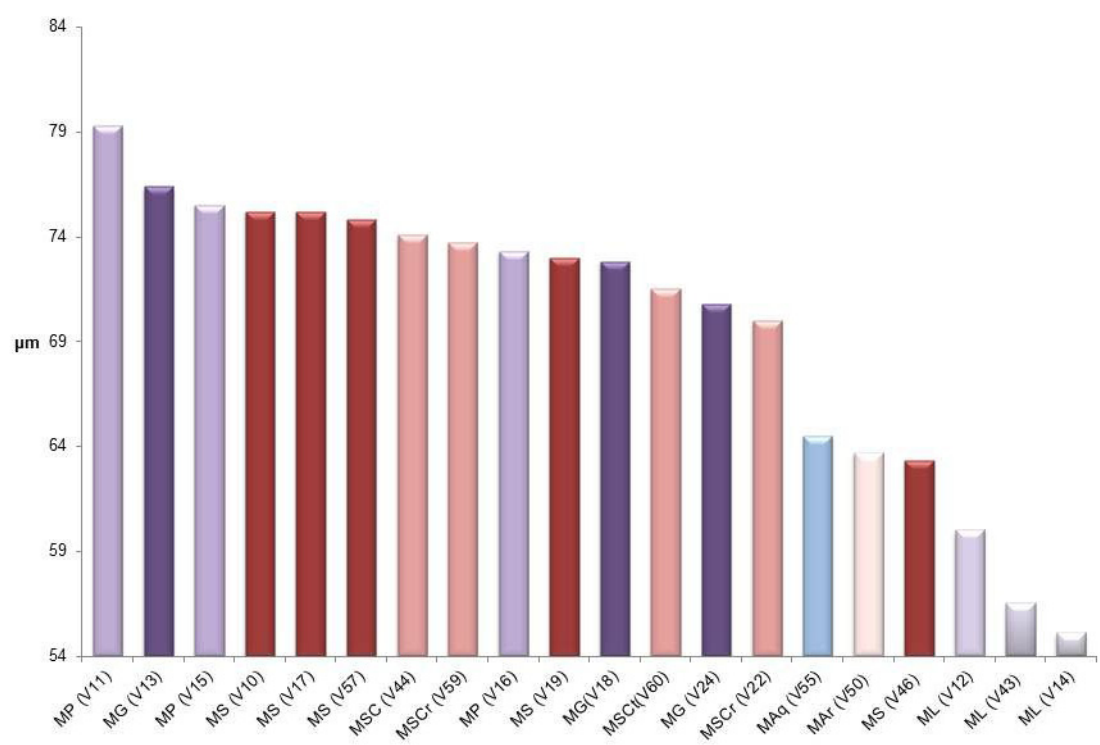

Figure 3. The size of PGT in $\mu$ m on abaxial surface of different mints.

MP - M. × piperita, MS - M. spicata, MSC - M. spicata subsp. condensata, MSCr - M. spicata var. crispa, MSCt - M. spicata var. citrata, MG - M. $\times$ gentilis, MAq - M. aquatic, MAr - M. arvensis, $M L-M$. longifolia 
The exploitation of micromorphological parameters for identification in the section mentha

Table 2. The results of measurements of leaf length and the number of peltate glandular trichomes.

\begin{tabular}{|c|c|c|}
\hline Sample & $\begin{array}{l}\text { Average leaf length } \\
{[\mathrm{cm}]^{*} \pm S D}\end{array}$ & $\begin{array}{c}\text { PGT average density on } \\
1 \mathrm{~mm}^{2} \pm \mathrm{SD}\end{array}$ \\
\hline M. $\times$ piperita $(\mathrm{V} 11)$ & $4.0 \pm 0.36$ & $8.1 \pm 2.14$ \\
\hline M. $\times$ piperita (V15) & $2.5 \pm 0.25$ & $12 \pm 1.79$ \\
\hline M. $\times$ piperita $(\mathrm{V} 16)$ & $3.9 \pm 0.25$ & $8.3 \pm 0.89$ \\
\hline M. spicata (V10) & $1.9 \pm 0.15$ & $9.1 \pm 1.42$ \\
\hline M. spicata (V17) & $4.1 \pm 0.40$ & $\mathbf{8 . 1} \pm 0.42$ \\
\hline M. spicata (V19) & $4.3 \pm 0.45$ & $3.7 \pm 0.21$ \\
\hline M. spicata (V46) & $\mathbf{2 . 7} \pm 0.33$ & $4.4 \pm 0.81$ \\
\hline M. spicata (V57) & $6.3 \pm 0.51$ & $4.3 \pm 0.4$ \\
\hline M. spicata var. crispa (V22) & $3.6 \pm 0.35$ & $4.8 \pm 0.64$ \\
\hline M. spicata var. crispa (V59) & $3.0 \pm 0.35$ & $10.91 \pm 1.95$ \\
\hline M. spicata var. citrata (V60) & $3.5 \pm 0.39$ & $14.73 \pm 2.16$ \\
\hline M. spicata subsp. condensata (V44) & $4.7 \pm 0.51$ & $10.9 \pm 0.93$ \\
\hline M. $\times$ gentilis (V13) & $\mathbf{2 . 8} \pm 0.25$ & $3.6 \pm 0.31$ \\
\hline M. $\times$ gentilis (V18) & $3.8 \pm 0.42$ & $5.6 \pm 1.7$ \\
\hline M. $\times$ gentilis (V24) & $4.9 \pm 0.45$ & $4.1 \pm 0.2$ \\
\hline M. longifolia (V12) & $2.3 \pm 0.24$ & $13.1 \pm 2.27$ \\
\hline M. longifolia (V14) & $2.2 \pm 0.17$ & $14.7 \pm 3.07$ \\
\hline M. longifolia (V43) & $4.8 \pm 0.46$ & $\mathbf{9} \pm 0.21$ \\
\hline M. arvensis (V50) & $3.6 \pm 0.36$ & $3.6 \pm 0.76$ \\
\hline M. aquatica (V55) & $4.1 \pm 0.39$ & $1.2 \pm 0.31$ \\
\hline
\end{tabular}

${ }^{*}$ Average is count from 10 leaves observations; SD - standard deviation

It is difficult to distinguish species with similar sizes of PGT, but this parameter could be important for the characterization and description of the species. The significantly smallest PGT were found in three populations of M. longifolia (55-60 $\mu \mathrm{m})$. We suggest that a large number of PGT in M. longifolia populations could compensate a relatively small size of PGT, while maintaining the relatively high content of essential oil $(2.5 \%[\mathrm{~V} / \mathrm{m}]$, unpublished results). Our observations confirmed previous results of published papers (Fialová et al., 2011; Šarić-Kundalić et al., 2009) and thus it appears to be one of the most important evaluation criteria for this species.

\section{Phytochemical parameter}

Third step of our research was GC MS analysis of essential oil of investigated mints. For a clear distinction of Mentha species it is important to establish phytochemical parameters. In this work we identified and quantified determined the main components of essential oil, which significantly vary from species to species. The main compounds important for identification are presented in Table 3. As it is markedly the investigated mints could be divided in 2 groups according their essential oil: menthol type and carvone type. In interpretation of results, it is necessary to consider that compounds in essential oil of one species could vary depending on variety, cultivar or chemotype. To know the main compound in essential oil is very helpful in identification, but also this phytochemical parameter as a sole identification parameter would be not sufficient.

\section{CONCLUSION}

Exploitation of micromorphological observation in identification seems not to be sufficient for all mints. The measurement of the size of PGT, supported by counting of PGT number on 


\begin{tabular}{|c|c|c|c|c|c|c|c|c|c|c|c|c|c|c|c|c|c|c|c|c|c|c|c|c|c|c|}
\hline 经 & $\stackrel{\operatorname{Ln}}{\sim}$ & & & & & & & & & & & & $\stackrel{n}{\stackrel{n}{N}}$ & & $\begin{array}{l}\infty \\
\stackrel{N}{\sim}\end{array}$ & & & & & & & & & & & $\stackrel{\infty}{\infty}$ \\
\hline घิ & & $\begin{array}{l}\mathscr{0} \\
\stackrel{0}{0}\end{array}$ & & & & & $\bar{m}$ & & & $\stackrel{+}{\mathrm{N}}$ & & & & & & & & & $\stackrel{9}{\longrightarrow}$ & & & & & & & \\
\hline$\frac{7}{7}$ & & & $\overline{i n}$ & & & & & & & & & & & & & & & & & & & $\stackrel{g}{m}$ & $\bar{i}$ & $\infty$ & & \\
\hline$\stackrel{n}{\exists}$ & & & & & & & & & & ğ & & & $\nabla$ & & & & $\underset{B}{m}$ & & & & & & $\stackrel{\stackrel{m}{*}}{*}$ & & & \\
\hline 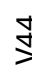 & กุ & & & & & & & & min & in & & $\begin{array}{l}\infty \\
\stackrel{\sim}{\mathcal{Y}}\end{array}$ & & & & & & & & & & & & & & \\
\hline$\stackrel{\Xi}{\Xi}$ & & & & & $\stackrel{\infty}{\stackrel{\sim}{*}}$ & & & & & & & ڤ̊ & & กี & & & & & & & & & & & in & \\
\hline$\stackrel{m}{z}$ & & & & & $\stackrel{m}{m}$ & & & & & 吕 & $\begin{array}{l}n \\
0 \\
0\end{array}$ & & $\hat{m}$ & & & & & & & & & & & & & \\
\hline$\stackrel{\infty}{z}$ & $\wedge$ & $\stackrel{\text { ํㅜㄹ }}{=}$ & & & & & & & & & & $\stackrel{m}{\stackrel{m}{N}}$ & $\bar{\infty}^{-}$ & & & & & & & & & & & & & \\
\hline $\mathscr{J}$ & & & & & & & & $\nabla$ & $\stackrel{\mathscr{n}}{\underset{I}{ }}$ & & & 웅 & & & & & & & & ğ & & & & & & \\
\hline$\lesssim$ & & & & & $\stackrel{n}{+}$ & & & & & & & 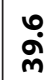 & & $\stackrel{\nabla}{6}$ & & & & & & & & & & & $\stackrel{\nabla}{\text { ì }}$ & \\
\hline 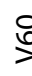 & $\stackrel{0}{=}$ & & & & & $\stackrel{\circ}{m}$ & & & & & & $\dot{y}$ & & જ̆ & & & & & & & & & & & & \\
\hline ஸे & & & & & & & & $\stackrel{\infty}{\sim}$ & $\stackrel{m}{\stackrel{m}{S}}$ & & & $\stackrel{+}{\stackrel{ }{m}}$ & & & & & & & & & & & & & $\stackrel{\nabla}{\text { in }}$ & \\
\hline$\frac{\circ}{5}$ & & & & & & & & $\stackrel{9}{r}$ & $\stackrel{\infty}{=}$ & & & $\stackrel{\infty}{\stackrel{\infty}{f}}$ & & & & & & & & $\stackrel{q}{+}$ & & & & & & \\
\hline is & & & & & & 0 & & & ma. & & & $\stackrel{n}{\mathbb{N}}$ & & & & & & & & $\infty$ & & & & & & \\
\hline 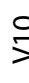 & & & & & & & & & $\stackrel{ナ}{+}$ & & & กุ. & & $\stackrel{\sim}{m}$ & & & & & $\hat{m}$ & & & & & & & \\
\hline $\bar{z}$ & & & & & & ชี & & $\stackrel{\leftrightarrow}{\sim}$ & $\stackrel{\infty}{\check{I}}$ & & & ণั่ & & & & & & & & & & & & & & \\
\hline 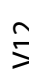 & & & & 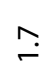 & & & & & & $\underset{\infty}{m}$ & & & & & & & & & $\bar{m}$ & & & & $\begin{array}{l}0 \\
\dot{H}\end{array}$ & & & \\
\hline$\frac{c}{z}$ & $\stackrel{m}{n}$ & & & & & & & & & & & & & & & $\underset{\ddot{y}}{\dot{y}}$ & & & & & $\stackrel{n}{\sim}$ & & & & $\stackrel{\infty}{\infty}$ & \\
\hline$\stackrel{n}{7}$ & & & & & & & & & & & $\stackrel{\circ}{=}$ & & & & & 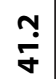 & & $\stackrel{\circ}{\circ}$ & & & 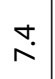 & & & & & \\
\hline 7 & & & & & & & & & & & $\stackrel{\infty}{\stackrel{\infty}{0}}$ & & & & & $\underset{J}{\dot{J}}$ & & $\hat{o}$ & & & જ઼ & & & & & \\
\hline & 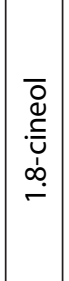 & $\begin{array}{l}\bar{D} \\
\stackrel{C}{0} \\
\mathbb{Z} \\
o \\
m\end{array}$ & $\begin{array}{l}\overline{0} \\
\overline{\underline{0}} \\
\stackrel{d}{J} \\
i\end{array}$ & 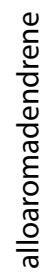 & 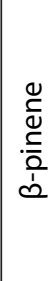 & 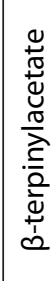 & 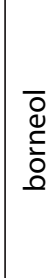 & 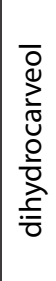 & 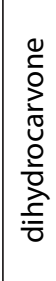 & 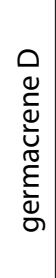 & 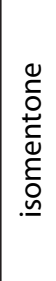 & 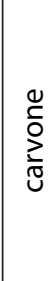 & 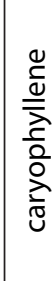 & 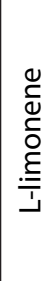 & 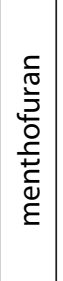 & 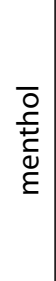 & 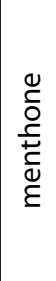 & 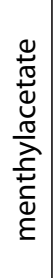 & 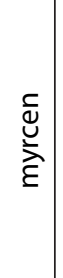 & 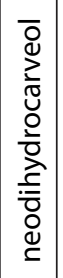 & 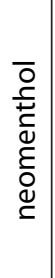 & 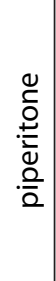 & 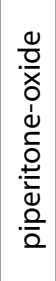 & 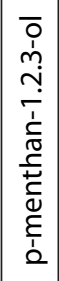 & 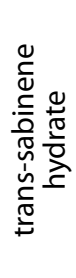 & $\begin{array}{l}\overline{0} \\
\overline{0} \\
\frac{0}{\bar{T}} \\
\frac{\overline{0}}{>}\end{array}$ \\
\hline
\end{tabular}


The exploitation of micromorphological parameters for identification in the section mentha

selected area, allows us to distinguish some individual taxa. Anyway, micromorphology along with phytochemical analysis is appropriate tool in Mentha identification and characterization; nevertheless it still needs further research.

\section{References}

[1] Tucker AO, Naczi RFC. Mentha: An Overview of Its Classification and Relationships. In: Lawrence BM. Mint. The genus Mentha. Medical and Aromatic Plants - Industrial Profiles. Boca Raton, London, New York: CRC Press, Taylor \& Francis Group; 2007.

[2] Lawrence BM. The Composition of Commercially Important Mints. In: Lawrence BM. Mint. The genus Mentha. Medical and Aromatic Plants - Industrial Profiles. Boca Raton, London, New York: CRC Press, Taylor \& Francis Group; 2007.

[3] Gershenzon J, Maffei M, Croteau R. Biochemical and histochemical localization of monoterpene biosynthesis in the glandular trichomes of Spearmint (Mentha spicata). Plant Physiol. 1989; 89:1351-7.

[4] McCaskill D, Gershenzon J. Croteau R. Morphology and monoterpene biosynthetic capabilities of secretory cell clusters isolated from glandular trichomes of peppermint (Mentha piperita L.). Planta. 1992; 187:445-54.

[5] Fialová S, Halušová L, Leitmanová G, Tekel'ová D, Grančai D. Hodnotenie vybraných druhov rodu Mentha L. na základe kvantitatívnej analýzy silicových orgánov. Farm Obzor. 2011; 80:165-8.

[6] Šarić-Kundalić B, Fialová S, Dobeš Ch, Ölzant $S$, Tekel'ová $D$, Grančai D, Reznicek G, Saukel J. Multivariate numerical taxonomy of Mentha species, hybrids, varieties and cultivars. Sci Pharm. 2009; 77:851-76.

[7] Felklová M, Nátherová L, Lindauerová T. Siličné orgány na listech různých taxonů rodu Mentha L. Českoslov. Farm. 1986; 35(1):1 - 5.

[8] Nátherová L', Lindauerová T. Silicové orgány na listoch súkvetia niektorých taxónov rodu Mentha L. Farm.Obz., 1986; 55(6):241-7.

[9] Maffei M, Chialva F, Sacco T. Glandular trichomes and essential oils in developing peppermint leaves. New Phytol. 1989; 111:70716. 